\title{
'Aeon' as an Expression of Metaphysics of Transcendence and Metaphysics of Immanence in John Damascene
}

\section{Introduction - The Words as the main source and proof of the authenticity of the Christian teaching}

A particularly interesting question raised by John Damascene (676749 AD) in his treatise entitled An exact Exposition of the Orthodox Faith ${ }^{2}$ is what the precise meaning of 'aeon' is, as well as what its ontological meaning is and to which realities one may attribute it. Furthermore, a clear, as far as possible, definition of the concept, a description of its properties and its relation with both the divine reality and the created world can be considered as parts of a holistic approach in a question with many aspects that both Christianity and Neoplatonism faced. Quite remarkable is the fact that throughout the entire reasoning, John Damascene combines really well Cosmology, Eschatology and Henology, and proves, on the one

1 Dr. Lydia Petridou: Academic Staff-Counsellor of Philosophy, at the School of Humanities, in Hellenic Open University; e-mail: petridou.lydia@ac.eap.gr, ORCID: 0000-0002-0055-5685. Christos Terezis: Professor of Ancient Greek and Byzantine Philosophy, at the Department of Philosophy, in University of Patras in Greece; e-mail: terezis@upatras.gr, ORCID: 0000-0003-4393-5247.

2 We have to mention that this is the title of the third part of John Damascene's

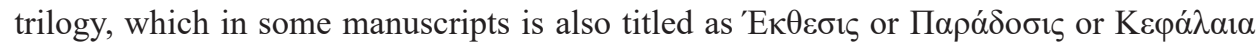

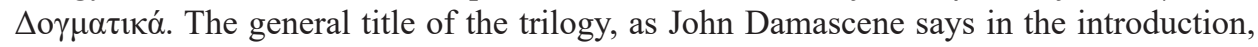

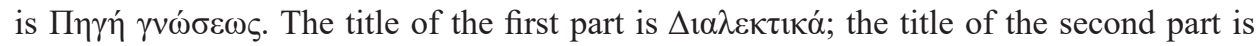

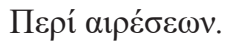


hand, the close relation of the entire created world with the divine reality and, on the other, the teleological prospect in which the natural universe develops ${ }^{3}$. This is actually an ontological connection between the effects and the supreme Cause, which is manifested as a perpetual revelation of the divine providence within the created world and an inherent tendency of the created beings to reach the One-Good. In this context, the fact that aeon has many meanings determines the arguments to be exposed and reveals indirectly the moderate conceptual realism followed by Christian thinkers ${ }^{4}$.

3 According to A. Louth, "John prefaces his discussion of the created order with a chapter each on the meaning of aion (aeon) and on creation. There are probably two reasons for the preliminary chapter on aion. First, in Platonic and Neoplatonic usage aion belongs before creation, creation being based on an eternal model (the word aion can be translated either 'eternity' or 'age'), time itself being a 'moving image of eternity'. Against this John asserts the transcendence of the Christian God, 'who exists before the ages', and indeed is their creator (Expos. 15. 2). Secondly, he comments on the different ways in which aion is used, and puts forward what he regards as its true metaphysical meaning. He thus lists some of these ways: of a human life, a millennium, the present age, the age to come being 'that age without end after the resurrection' (Expos. 15. 8-9). He mentions the notion of the seven ages of the universe, the eighth being that which is to come. But the most important use of aion is in distinction from time (chronos): the latter is measured by the course of the sun, by days and nights, whereas aion is a 'kind of temporal movement and extension that embraces everlasting (aïdiois) beings; what time is for those subject to time, aion is for everlasting beings' (Expos. 15. 11-13). This was the 'time' before creation, and so God can be called aiônios, but he can also be called proaionios, 'pre-eternal', for he transcends the aion, which he created. But aion is also the 'time' after this age has passed away: it is 'eschatological time', the time without end that characterizes the age to come, where there is no measuring of time by days and nights, but 'rather there is one day without evening where the sun of justice shines brightly on the just, while for sinners there is a deep interminable night' (Expos. 15. 33-5). But the fundamental point that John wants to make is that aion, or eternity, belongs to the created order, distinct from time by virtue of being beyond measure, but 'of all the ages God is the one creator, who fashioned the universe, who exists before the ages' (Expos. 15. 36-8). This teaching on eternity is very similar to that found in earlier Christian theologians, such as Dionysios and Maximos" (St. John Damascene: Tradition and Originality in Byzantine Theology, Oxford 2002, p. 117-118). On this topic in pseudo-Dionysius the Areopagite, cf. De divinis nominibus, PG 3, 937C-940A. In Maximus the Confessor, see Ambigorum liber, PG 91, 1164 A-D. It should be mentioned though, as A. Louth mentions, that Maximus tends to preserve the term aïdios for God himself. Cf. for instance, capitum theologicorum et oeconomivorum duae centuriae, PG 90, 1085 A-B.

4 L. Benakis, To próvlīma ton genikón en noión kai o ennoiologikós realismós ton Vyzantinón, "Filosofía" 8-9 (1978-1979) p. 311-340, who also presents the former Neoplatonic performances on this topic and utilizes all the relevant literature. 
Referring to the $\operatorname{Words}^{5}$, that is, the divinely inspired texts - which are considered to be the sources of the internal cognitive procedures which take place in order human being to exceed pathogenic conditions and to gain great knowledge, which have been eventuated after a long attempt to understand the divine mystery - John Damascene points out that their content results in the renewed and constantly improving dialectic relationship between the two levels, namely, the uncreated and created ${ }^{6}$. Undoubtedly, renewal and improvement are related to initiatives undertaken by the created world, since the divine has been completely expressed from the beginning. It should not escape attention though that the point of view of both the Words and John Damascene is anthropocentric, in the sense that human mind is considered to be the factor that has great access to the projection and experience of the divine Revelation. The perspective in which these are included is quite clear: any reference to the biblical texts aims at confirming a particular knowledge of an undeniable reality. In this sense, both the Words and the theology inspired by the Holy Spirit - which John Damascene represents - constitute the only demonstrative path that shows the way -as much as possible - to the Unutterable and Unknown that is considered to be the only objectively existing reality. This is an ontological and gnoseological combination that underpins the relation of the apophatic with the affirmative theology.

Referring to the Words, John Damascene says the following: $\dot{\alpha} \pi$ ò $\tau o \tilde{v}$

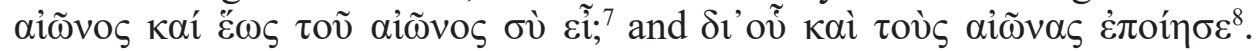
These extracts show the infiniteness of God, who has no beginning or end, but permanently is. By using the present tense eĩ (is), God is recognized to

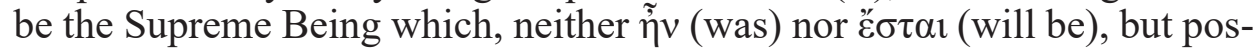
sesses and constantly provides the existing world with the property of being. It should be mentioned that God may not be placed within time, not

5 For a systematic research on the Words in Christianity, see R. Roques, Structures théologiques de la Gnose à Richard de Saint-Victor, Paris 1962.

6 Joannes Damascenus, De fide orthodoxa libri quattuor (hereafter f.o.), ed. Bon. Kotter, Die Schriften des Johannes von Damaskos, v. 2, Berlin-New York 1973, 15, II 1,

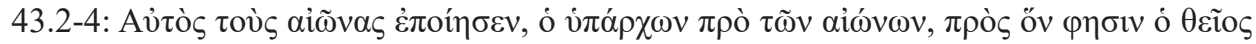

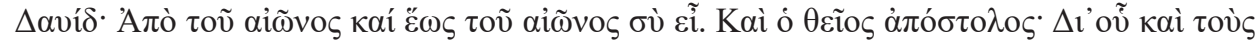

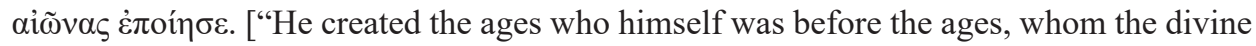
David thus addresses, From the age to age Thou art. The divine apostle also says, Through Whom He created the ages" (trans. by S.D.F. Salmond, 525)]. This extract is quite typical of a Christian approaching ontologically the fact that God is not just the arranger but also the creator of all things ab initio. So, Cosmology has to be related with Ctisiology.

\footnotetext{
7 Ps. 89,2.

8 Hbr. $1,2$.
} 
even in the senses of beginning or end, but, since he is considered to be the only Cause, he is the transcendent entity that determines the context, i.e. the terms of the creation and the regulatory rules of the development of the created reality, that is, of the world which includes both the supersensible and the sensible beings. According to the " $\delta$ ' $o v$ " and the context of the second extract, one could argue that indirectly the divine triadicity arises, which is God's personal state that manifests in a creative way by means of the Son and Logos. Parenthetically it is to be said that John Damascene will later discuss these points more clearly. By understanding, however, the Christian thinker's words, both the united theology, which stresses that the divine nature is not subject to space, and the distinct theology, which suggests that the unified substance is shared among the three persons in exactly the same way, arise. That is, he discusses topics that have been already elaborated by pseudo-Dionysius the Areopagite?

Another thing to mention is that God is three-hypostatic because of the paternal beginningless divine "procession", which reveals - not though in the sense of succession, dependence or determination - the Son and the Holy Spirit. That is to say, the divine "procession" is a somehow starting point, from which any relation or sequence or a priori distinction within God arises; however, these states are set in a self-founding way. Note also that the distinctions - the Father, Son, and Holy Spirit - do not precede the union - namely, the divine substance - since unity is the dominant reality, while distinction just reflects its infinite internal richness. By these remarks, John Damascene actually updates pseudo-Dionysius' teaching. So, any kind of ontological - or any other kind of - priority of the persons over the substance is not in accordance with the Christian metaphysical theory or John Damascene's beliefs. On the other hand, realistic ascents are pointed out too, according to which the existence of the supreme Principle is confirmed to be existing independently from other thinking beings, which are able to perceive and understand the truth up to a point. In this perspective, God, as the originally existing being, the provider of being

9 Cf. A. Louth, Denys the Areopagite, London - New York 2002, p. 88-91. It is to be mentioned that God's names being, essence and substance do not describe his original unparticipated nature but one of his energies, which are considered to be participated. The fifth chapter of pseudo-Dionysius the Areopagite's treatise entitled De divinis nomi-

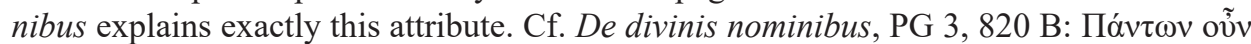

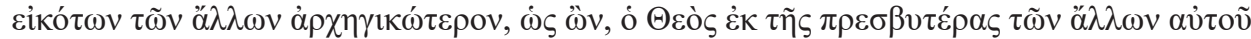
$\delta \omega \rho \varepsilon \tilde{\omega} \nu$ v $\mu v \varepsilon i \tau \tau 1$. ["Almighty God is celebrated as Being, from the prior of His other gifts" (trans. J. Parker, Dionysius the Areopagite, Works (1987) by Dionysius the Areopagite, Ipswich 2004, p. 43)]. Cf. Georgius Pachymeres, Paraphrasis Ps.-Dionysii "De divnis nominibus" ad loc., PG 3, 840 C. 
and the only Cause of all other beings, is superior to them. In other parts of his work, John Damascene analyzes that the relation between the Cause and its effects depends on the divine will, which exactly as divine intention excludes the possibility of any productive necessity. Undoubtedly, there is a mutual relationship between the two levels, which participate in it in different terms: provided that we take into consideration the fact that all the effects do not come directly from the divine substance but they are expressions and manifestations of the initiatives of the divine energies.

\section{The relation between aeon and the created world and the combination of Cosmology with Eschatology}

Under these terms and conditions, John Damascene presents more specific thoughts on the meanings of the concept of 'aeon' by making clear from the beginning that there is a number of them. One could say that this polysemy is due to the investigation of what is possible to be understood by human mind as true. Thus, according to the Christian thinker aeon may be distinguished into created and infinite ${ }^{10}$. In this perspective, the Christian thinker points out that the life of every human being may be considered as aeon ${ }^{11}$. This is a totally intra-world orientation, which is actually related to what is sensibly perceived and, consequently, to which are the terms

10 It should be mentioned that according to N. Matsoukas, Dogmatiki kai Symvoliki Theología, v. B, Thessaloniki 2003, 183-186, all the meanings describe a common representation: duration, movement, space. So, one could argue that when "aeon" is related to God, it means the eternal movement; when it is related to the created beings, it means the relevant movement. The purpose of a clear definition of the createdness of the aeon is to show that creation is first and foremost duration, movement, life, variety, course, and completeness. What is more, although both the intelligible and the sensible aeons come before the creation process, they are associated with the direct presence of the beings. Note also that God, who is eternal, is essentially completely different from the created reality, since he is beyond time and aeons, no matter what their meaning is. So, this is a meaning by analogy, that is, eternity has a different meaning in each level and, therefore, it is important to define each time to which ontological level we refer.

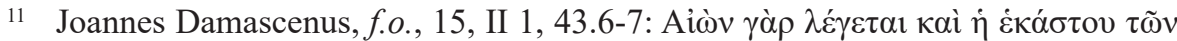
$\dot{\alpha} v \theta \rho \omega \dot{\pi} \omega v \zeta \omega \eta$. ["The life of each man is called an age" (S.D.F. Salmond, 525)]. This is a point of view that shows - at least indirectly - conceptual realism, which explains

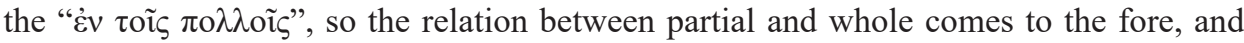

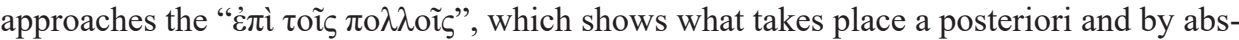
traction by the sensible genera within human mind, so mentalism is also pointed out. 
of the sensible world. In fact, here aeon is identified with one aspect of the secular time, but not with all of it, in the sense that it is a specific part of the development of a living being, which, as an effect within time, is created and corrupted. This circle is associated with the natural law and presents a regular recurrence, since it is a proof of the order that God himself set in terms of repetition in his creation. And precisely this succession defines time as a general state closely related to motion, which shows the interchange-alternating sequence of the time points. As it will be later explained, time is measured by the movement and the orbit of the sun, which is composed by days and nights; this perspective is often found in the Bible as well as other philosophical theories and associates space with time, the two cosmological factors on which sensible beings depend. Special attention is required here, for the secular time is actually identified to the cyclical nature; taking into account the inevitable recurring events, this point may lead to the fundamental law of time, that is, it shows the eternal reversion of the things to the original point ${ }^{12}$. So, the fertile engagement of physics with metaphysics comes to the fore, at least on a functional level, which according to the context is related to eschatology.

Remaining at the created level, John Damascene goes further from that initial meaning about a specific period of time from the moment of creation to the natural end of a human life, and explains that 'aeon' can also be considered as a period of a thousand years ${ }^{13}$. This is a scientific extension which is related to mental states, language conventions and interpretative codes, in the context of a microcosmic approach of the indefinite macrocosm. The truth about 'aeon' here concerns numerical references, which reflect a specific meaning that is based on a certain pragmatological finding quite understandable by human beings. In other words, it is suggested that a meaning connects the reference with the terms of truth and both of them with knowledge, which is based on experience. It is an experience that is evidenced by visible external conditions, not easily predictable, which develop into mental states and linguistic schemata. Actually, taking into account that intellectuality is actually a natural phenomenon, the intra-world orientation - in the sense of the perpetually changing becoming - that John Damascene attempts to show appears much clearer.

12 For a more systematic approach, cf. Qo. 3, 1-8. For a holistic approach of the context of this extract, see Gregory of Nyssa' Homilia 6 on Ecclesiasten (PG 44, 676 A-712 A). In his work, the Cappadocian Father makes an impressive interpretation of the extract, utilizing the method of allegory and attempting to relate the Old Testament with the New Testament; he also uses material from the Greek philosophical tradition.

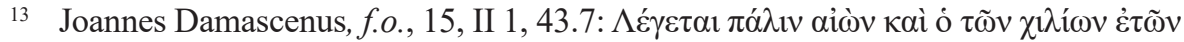

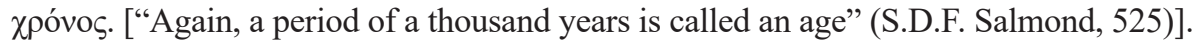


Introducing some metaphysical aspects, John Damascene combines Cosmology with Eschatology, suggesting that the present life, as well as the future one, which will follow after the expected event of resurrection, may be also called 'aeon'14. At this point, he speaks about the historical time and its eschatological perspective, in the sense of a transformation that is beyond time. From the first point of view, 'aeon' is the manifestation of the divine economy in history, i.e. unique events which hold a key role to the actualization of the pre-eternal divine will, from which the prospect of the teleological motion of creation is actually proved. This is definitely a qualitative reevaluation of secular time, which shows something totally new: time becomes somehow sacred because of the special meaning that it receives due to the divine will, which activates the "procession" in the sense of an exodus from the state of "remaining", or, in the sense of a theophany and creative action, because of which all the world comes into existence from non-being.

However, there is also another aspect to consider. Specifically, between two interconnected terms, the beginning and the end, history in the sense of the present aeon is formed by the ontological foundations set by the two opposite motions: the "processional" motion of the Good and the opposite of it, the moral fall as a somehow development of evil. Clearly, they are not two equal forces, since the omnipotence of the supreme Principle is undoubtedly inviolable. Furthermore, evil is not an actual fact that could be ontologically similar to the transcendent. So, it could be argued that the whole idea is about how the tendency of the created beings towards the Good can actually be activated, while the tendency towards evil has been already developed, after the evil itself has appeared. First of all, it should be mentioned that the freedom according to image of God is by definition anthropologically ensured. However, there is one condition for this freedom to exist: there should be a clear chance to choose between two opposites. And this is something that somehow shows the moral fall found within the created world, that is, evil appears as a choice against nature. On the other hand, the eschatological perspective of time does not allow present things to consolidate, for it shows the future as the point of the radical termination of the continuity of the present century, i.e. of the world that is subject to corruption and change, and the future eighth century - according to John Damascene - which will start after the resurrection. Special

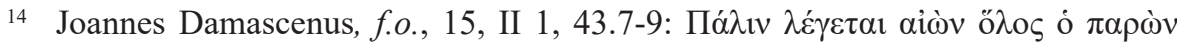

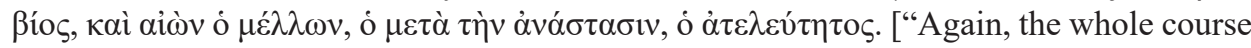
of the present life is called an age: also the future life, the immortal life after the resurrection, is spoken of as an age" (S.D.F. Salmond, 525)]. It is quite clear that this is not just a difference of the quantity, but also a difference of the quality of the existence. 
attention is required here, since one should avoid a simplistic or automatic interpretation of the above-mentioned. So, the most important thing is to understand time as a whole of three points, the present, past, and future, so as the real orientation of its course to emerge. A determining kind of teleology appears here, which makes understandable, at least to a point, the spiritual demands raised in the present aeon so as the completeness of the future one to follow. From the qualitative point of view, teleological-eschatological time is dimensionless.

Insisting on the created world and taking into account the regulatory terms set by Metaphysics, John Damascene relates 'aeon' with the 'eternal' beings, which, on the one hand, are creatures, and that is why they have a beginning, but, on the other hand, they co-exist together with eternity, since they have received by God the superior property of immortality, so they do not have an end ${ }^{15}$. Therefore, the main quality of their existence, which is due to the fact that they participate in aeon, is a perpetual being. However, this is a participation that eliminates any absoluteness and shows that these created beings, as effects, depend on a superior reality and that is why their abilities are limited. A term to mention here is 'angelic changeability', provided that this is not about the angels' essence but about their thought and will, and that we are describing intangible created beings that have come into existence a posteriori. Considering the axiological hierarchy of beings in Christian theory, it becomes clear that the non-sensible angels, since they go beyond the perpetual cycle of genesis and corruption, are believed to be superior to the sensible world. They are not equal to the divine reality, but in the context of a theoretical economy, they receive a name appropriate only for the superior Principle. In this way, the created world comes closer to eternity, while 'aeon' becomes the metaphysical measure that shows the overcoming of the terms of becoming; and this concerns both the supersensible beings and God himself. Furthermore, according to John Damascene, 'aeon' is for eternal beings what time is for temporary beings, that is, an inherent property of theirs.

This interpretation - together with the fact that John Damascene has already made clear the relation of time with space - shows the paradigmatic

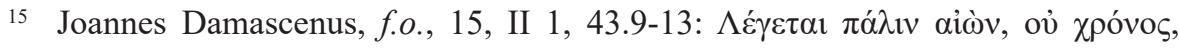

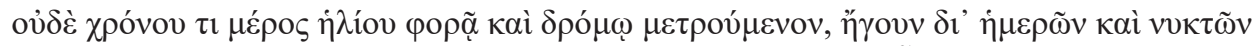

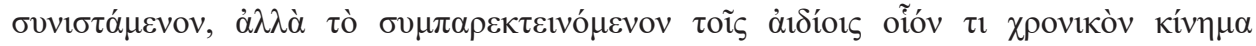

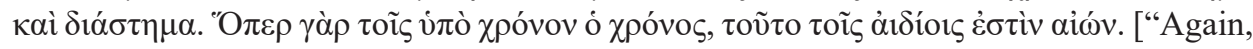
the word age is used to denote, not time nor yet a part of time as measured by the movement and course of the sun, that is to say, composed of days and nights, but the sort of temporal motion and interval that is co-extensive with eternity. For age is to things eternal just what time is to things temporal" (S.D.F. Salmond, 525)]. 
function of a concept over another, which brings us to Plato's Timaeus ${ }^{16}$. Furthermore, despite the fact that the discussion is not clear, it brings to the fore the eschatological interpretation of time and, by extension, the possibility to overcome the corrupting terms of an endless cyclically repetitive and recycling course of an automatic cosmology. In this sense, time is not just a monad to measure; instead, any motion in its ranks aims at leading beings to perfection ${ }^{17}$. The most important thing is once again the gradual realization of the teleological planning, an argument that this time is based on that a sensible being is able to exceed the world of becoming. Furthermore: any development or process that takes place in the sensible world, is a kind of participation to the above-given properties and, in our opinion, this is a movement towards the formation of something ontologically completely new.

Going further, John Damascene makes a critical explanation: 'aeon', despite the fact that has many meanings, when it is related to the created world, is not just one, but seven. By this remark, the Christian thinker shows how the concepts "one-multitude", with the former being associated with the divine reality and the later being related to the created world, are connected with each other. Furthermore, any interpretation made about the created world is different and, since it is no more about God who neither may be expressed in words nor can be understood by human mind, is associated with the concept of "many". In fact, we are speaking about a difference on the ontological nature of the two levels, the created and the uncreated, from which many consequences arise; the principle though of the ascending transition starts from the created world and reaches, as far as possible, God. So, from the moment of creation of heaven and earth to the general end and resurrection of human beings, aeons are according to

16 Plato, Timaeus, 29a.6-29b.2; 37d.7 (Platon Oeuvres completes Timee et Critias, ed. A. Rivaud, Paris 1925). It should be mentioned here that Plato placed eternity outside the sensible world and did not approach it in the sense of a transition from one world to another. It should not, however, escape attention that, although he believed that time was created at the same time with that of the world, he suggested that it is the sensible and movable image of eternity as well. On the matter of time in Timaeus, see A.-J. Festugière, La révélation d'Hermès Trismégiste, v. 2, Paris 1990, p. 153-195. See also, E. Brann, Time in the Timaeus, in The Music of the Republic: Essays on Socrates' Conversations and Plato's Writings, Philadelphia 2004, p. 273-277. On how Neoplatonism deals with the topic of time and eternity, cf. E.R. Dodds, Proclus: The Elements of Theology, Oxford 1933, p. 227-230.

17 On the eschatological perspective of time in Christianity, cf. for instance, O. Cullman, Christ and Time: The Primitive Christian Conception of Time and History, transl. F.V. Filson, London 1962; L. Benakis, Chrónos kai Aión, „Filosofía” 10-11 (19801981) p. 398-421; É. Gilson, L'esprit de la philosophie médiévale, Paris 1989, p. 63-132. 
the Christian thinker seven ${ }^{18}$. Therefore, both the space-time of the sensible beings and the intelligible reality of the angels, as well as of any other condition included in the created world, is measured by seven aeons ${ }^{19}$.

Special attention is required here, in order not to misinterpret the verb "measure". Apart from the fact that aeon has nothing to do with what has already been said, it is impossible to be defined by human beings and what they understand or are able to measure, since this would also cause the definition of the end of the present world and, accordingly, would define the starting point of the new, or, according to John Damascene, eighth aeon. It is an eschatological achievement completely impossible by any created being and for Christians it is possible only by God. Actually, the whole discussion here is metaphorical and leads to some parallel thoughts about the weekly time, in which each day symbolizes something. Thus, Sunday is the first day of creation, followed by another five, during which the divine "procession" unfolds, while in the seventh day the creative action of the One comes to an end, for it is completed. Sunday, however, as the day of the dominical resurrection of the Godman is also a type of the future aeon, since it brings closer the created

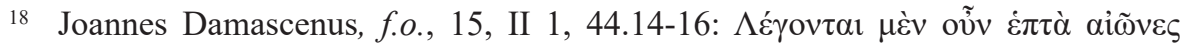

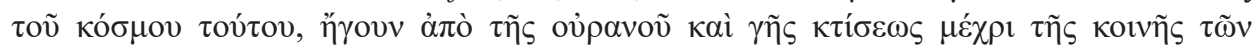

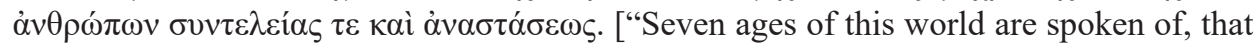
is, from the creation of the heaven and earth till the general consummation and resurrection of men" (S.D.F. Salmond, 525)].

19 Henology, both in Christian and Neoplatonic theory, is the highest theological point of the traditional Metaphysics. In Neoplatonism, it has been systematically discussed by Plotinus and elaborated by Proclus and Damascius. God is still the true being, but his greatest name is now the One, the origin of which lies in the Platonic dialogue Parmenides, and is also found in Aristotle. For a systematic approach of the topic, cf. P. Aubenque, Le problème de l'être chez Aristote, Paris 1991, p. 305-411, where the differences and similarities between Academy and Lyceum are described. Proclus' and Damascius' commentaries on Plato's Parmenides show the historical development of the topic. Generally, this is a tradition that is formed by Plato and Aristotle and concerns the theological characteristics of Metaphysis. Plotinus contributes to a further discussion. On this, cf. also, P. Aubin, Plotin et le Christianisme, Paris 1992, who explains the relation of the subject matter with the metaphysical and cosmological procedures, taking into account how it is presented during the third century by Neoplatonism and Christianity. On the concept of Henology, cf also, E. Schürmann, L'hénologie comme dépassement de la métaphysique, „Les études phi-

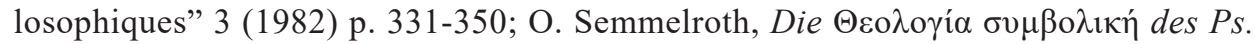
Dionysius Areopagita, ,Scholastik” 27 (1952) p. 1-11; J. Trouillard, Proclos, Eléments de Théologie, Paris 1965, p. 46; E.R. Dodds, Proclus. The Elements of Theology, Oxford 1933, p. 257-258. 
reality to the future eternal life ${ }^{20}$. If on the first day natural light was created, on the eighth day the transfiguring light was revealed, by which human nature was released from corruption. One could say that this weekly cycle symbolizes the time of human life as well as the time of the entire created world; so, this is actually the course of the created reality from the moment of creation to the end and the beginning of the future - eighth - aeon. Quite remarkable is here the distinction between the general and complete end and, consequently, the general resurrection and the partial end of every created being, namely, individual death, which results from the completion of the cycle of its life ${ }^{21}$. By this remark one is able to distinguish between the terms that apply at the plane of the created world, which falls under change, and those that God, as the omnipotent supreme Principle, imposes - in a positive way - to the created world.

This transfiguring process - which ends when the seventh aeon ends and the eighth new aeon begins - shows that the One is the only Principle of the created beings and the point to which they reverse, since it is the Good and the most desirable being to which all the created beings return after the completion of their evolution. So, on the one hand, God sets a strict regulatory framework in the development of the universe and, since the principles of that framework may change by him whenever it is necessary, lead the created beings to a purpose set by him. This reveals teleology. On the other hand, it seems that the world is not self-reliant and nothing happens accidentally, for the entire world follows a dynamic model. Moreover, the divine providence, which never ends, reveals the relation between the Cause and its effects, which is based on both transcendence and immanence. In this way, God is separated and actually comes before the created beings, while he also exists in those that he has already produced or he is going to produce in future as being the creator and the energy ${ }^{22}$. This is because in Christianity and its monistic model, anything, even the objective ontological facts of space and time, or the natural laws, for instance movement, depend on the One's will and intention and, more specifically, their

20 According to Basil the Great (Homilia 2 in hexaemeron, PG 29b, 52 B), it is

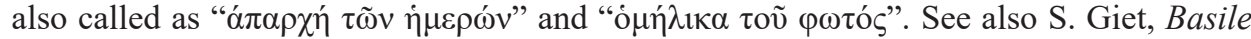
de Césarée. Homélies sur l’hexaéméron, Paris 1968, p. 184-187. Cf. Lev. 23, 36.

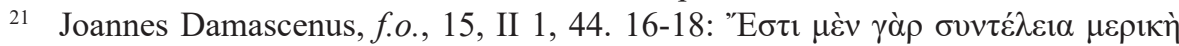

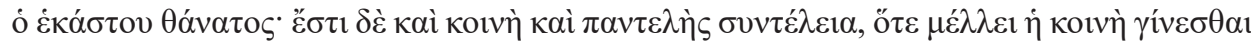
$\tau \tilde{\omega} \nu \dot{\alpha} v \theta \rho \omega \dot{\pi} \omega \nu \dot{\alpha} v \alpha \dot{\sigma} \tau \alpha \sigma 1 \zeta$. ["For there is a partial consummation, viz., the death of each man: but there is also a general and complete consummation, when the general resurrection of men will come to pass" (S.D.F. Salmond, 525)].

22 On the divine energy in John Damascene, see J.-C. Larchet, La théologie des énergies divines: Des origines à saint Jean Damascène, Paris 2010, p. 423-450. 
source is placed within the sphere of Metaphysics, in the sense that they are modes in which the divine creative activity is manifested.

\section{The relation between aeon and the divine reality and the combination of Henology with Eschatology}

From the henological point of view, John Damascene becomes more specific on the meaning of 'aeon', pointing out that before the creation of the world, when there was no sun - according to the motion of which day comes after night in an endless cyclical repetition - there was nothing that could be regularly measured, but only "aeon", which co-exists with the eternal beings - i.e. the angels - and can be somehow considered to be a form of temporal movement. The fact that this "aeon", which is one, is created is not something to wonder about, for, as it is stressed, it is produced, as any other created being or measure or generally phenomenon, by God and his productive activity ${ }^{23}$. However, because of this "aeon" God is named "eternal" and "pre-eternal" 24 . These are names which are attributed to the supreme Principle and show the endless life and the eternal being, in the sense of an infinite and everlasting self-founding being. Not only does a somehow temporal eternity appear, but also the prospect of overcoming corruption. In a more specific approach, the "eternal" God is beginningless, endless and independent from any limitation or change; but this does not mean that any "eternal" being is also beginningless, since the distinction between God and the angles has been made quite clear. Furthermore, the "eternal" God - as unchangeable - is considered with no

23 On the createdness of time and eternity and on the occasion of the pseudo-Dionysius' works, see for instance, O. Semmelroth, Gottes uberwesentliche Einheit. Zur Gotteslehre des Ps-Dionysius Areopagita, „Scholastik” 25 (1950) p. 209-234.

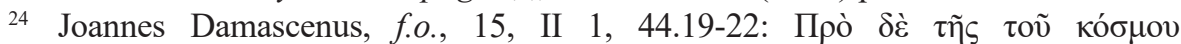

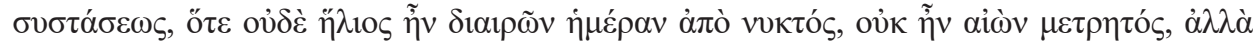

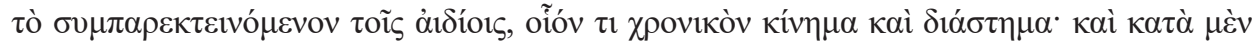

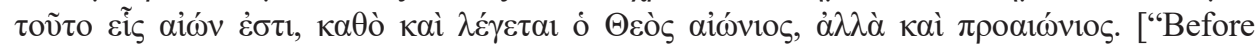
the world was formed, when there was as yet no sun dividing day from night, there was not an age such as could be measured, but there was the sort of temporal motion and interval that is co-extensive with eternity. And in this sense there is but one age, and God is spoken of as

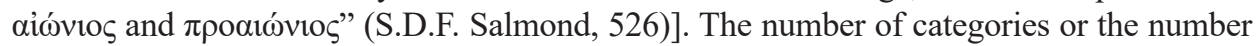
of the meanings relies on the principle of analogy. It should be mentioned that the term " $\delta 1 \alpha ́ \sigma \tau \eta \mu \alpha "$ should be understood in a metaphorical sense, as a way to exist in time. 
existential or ontological deficits, since his nature is stable and complete; these are metaphysical parameters which show that he internally possesses qualities that determine his existence, independently from any external terms. The temporal points may not be applied or interpreted in this level, since the One is the being that eternally exists and has no beginning or end, but it is from any point of view completely uncreated and eternal. So, God is the supreme reality and the model of the created world, who, as he is a true image, is not subject to the corruption found in the created world, which is obviously not everlasting. Theological realism as one of the factors that consistently establish henology is here quite obvious, both in the self-founding conditions and during the projections that cause new ontological states, which occur during the procedure of completeness.

It should be also mentioned that in this context, the concept of "creator" is also emphasized, which explains the name "pre-eternal", since God produces or is going to produce any being, part, whole, measure, and condition of the created world, even the aeons ${ }^{25}$. Moreover, as a term of eternal life, God exists before the creation of the world, a part of which is aeon, as an archetypical image, and time, as an intra-world sensible measure. Note though that under no circumstances should one think of the notion "pre-eternal" in the sense of a pre-cosmic temporality, for this would relegate the self-sufficiency of the divine substance and would confine the supreme Principle's freedom. Consequently, God would manifest himself together with anything that he includes by necessity ${ }^{26}$. Necessity would then be the feeding source of any active causality. On the contrary, the term "pre-eternal" describes the complete divine transcendence, which is ontologically required so as God to be considered as the only creator, who produces absolutely unconditionally and totally intentionally. The "before multitude" aspect of the conceptual realism of the Christians is here revealed, according to which God's simple thoughts are found all over the natural world as somehow instruments of his power. This approach shows how the creative divine reasons function, which are considered as Ideas and explain in a Christian way Plato's theory.

Going further, John Damascene explains a quite important point, which is closely related to henology: when we speak of "God" we mean the three

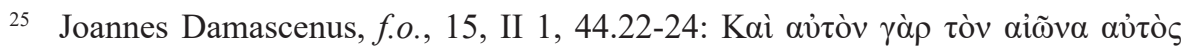

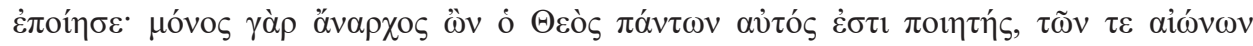

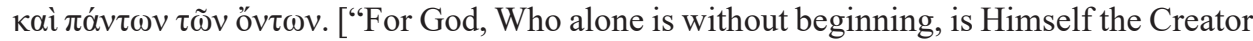
of all things, whether age or any other existing thing" (S.D.F. Salmond, 526)]. Monism is quite obvious here too.

26 G. Florovsky, Thémata Orthodóxou theologías, transl. S. Papalexandropoulou, Athens 1973, p. 9-32. 
divine hypostases, the Father, Son and Holy Spirit, which are not considered to be three separated gods, but a single one ${ }^{27}$. The topic that is actually here introduced is about the relationships developed between God himself and his somehow internally ad extra revelations, with the terms of "union" and "distinction" being used quite intensively. Consequently, it would be more accurate to use the terms of the divine "remaining" and the divine "procession" as a dynamic exodus from the state of "remaining"28. Under the ontological terms set by the united and distinct theology, the Christian thinker underlines the unity of the divine substance and - ontologically - specifies the names of each hypostasis that show the properties owned by one of them and not by the rest ${ }^{29}$. This is not a contradiction, for, first and foremost, the doctrine of monotheism is confirmed and, secondly, a distinction, not though a hierarchical one, is introduced. So, it becomes clear that he speaks about a methodological suggestion for investigating the divine reality in two cognitive ways, in order to avoid an inflexible conceptual confusion. In this context, the Dionysian tradition, which follows the rules set by Henology, is quite obvious.

Note also that unity does not result in a simplistic monism but a dynamic one, with the emerging consequences not changing at all the original ontological state. Particularity - and, metaphorically speaking, otherness - is a relation that shows a different direction in how God exists. This is actually the unity of the divine nature, which cognitively is totally incomprehensible by human mind. Moreover, this is another way of existing, the Father, the Son and the Holy Spirit. God appears to be both substance and persons. In this sense, there are a priori distinctions within the Holy Trinity. It should be explained, however, that it is not theologically right to suggest that distinctions - and not differentiations - come before unions, for unity is the dominant reality, while distinctions prove its infinite richness. Absolutizing them includes the risk of disproving monism. Or, in other words, considering the persons to be ontologically prior to the substance is not acceptable, since this is a doctrine that had been established since the fourth century by the Cappadocian Fathers, which defended the self-founding equality ${ }^{30}$.

27 Cf. P. Scazzozo, La teologia antinomica dello pseudo-Dionigi, „Aevum” 49 (1975) p. 6.

28 On union and distinction, see for instance, M. Töröner, Union and Distinction in the Thought of St. Maximus the Confessor, Oxford 2007.

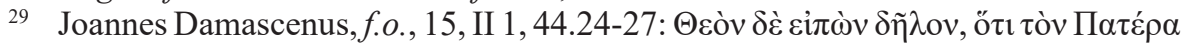

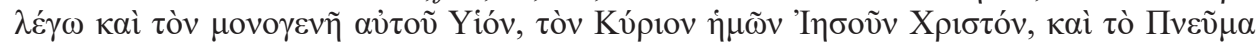

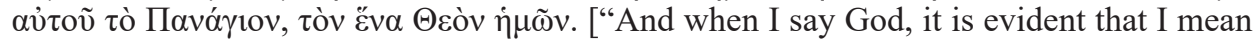
the Father and His Only begotten Son, our Lord, Jesus Christ, and His all-holy Spirit, our one God" (S.D.F. Salmond, 526)].

30 It is to be mentioned that the Cappadocian Fathers use more the term "hypostasis" than the term "person". Extensive use of the term "person" one can only find in Gregory

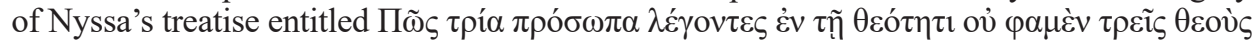


Therefore, the three persons are undoubtedly originally self-founded and equal to each other, for, otherwise, hierarchy and polytheism would arise ${ }^{31}$. On the other hand, in Christianity the divine substance may not be considered to be the creative or productive cause within God, for this would absolutize it in relation to the persons; moreover, it would be necessary to define which person was firstly produced and which followed. In fact, the right word to describe God's being is "unseparated". That is to say, neither union nor distinction comes first. That is why there is no hierarchy, as already mentioned, or any other kind of succession, which would mean that there is some form of development within the divine reality and God's way to exist. So, it could be argued that God becomes active in himself through his substance by means of the persons and that the way in which he exists may be described as communicative, because of both the triadicity and the union among the divine persons, in the sense that he is a substance that becomes distinct by his hypostatic idioms. This topic (on unions and distinctions) had already been raised since the fifth century by pseudo-Dionysius the Areopagite ${ }^{32}$ and the Neoplatonist philosophers Proclus $^{33}$ and Damascius ${ }^{34}$.

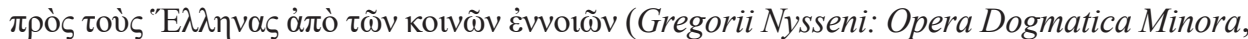
vol. III/1, ed. F. Mueller, Leiden 1958, 19-39; J.-P. Migne, PG 45, 176-185).

31 The above-mentioned result in what could be named as communion. God is one, since there is only one cause and one substance, but he is also three uncreated persons with the same substance, in the sense that they are individuals. The hypostatic idioms "ungenerated", "begotten" and "eternally preceded from the Father" are unshared and unmovable from each hypostasis. The way in which they are possessed is not something known to human. The divine self-founding integrity is permanently preserved. This topic has been thoroughly discussed by the Fathers of the Church. Cf. for instance, Gregory of Nyssa's

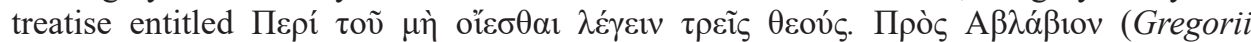
Nysseni: Opera Dogmatica Minora, vol. III/1, ed. F. Mueller, Leiden 1958, 37-57; PG 45, 116-136), who also discusses crucial anthropological questions.

32 Note that in the Dionysian corpus the theory on the divine "processions" - energies is systematically elaborated on the basis of the main ontological distinction between unions and distinctions of the supreme Principle, the One-Good. Tàs $\mu \dot{\varepsilon} v$

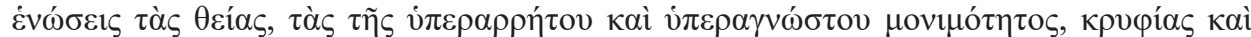

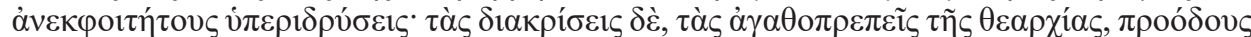

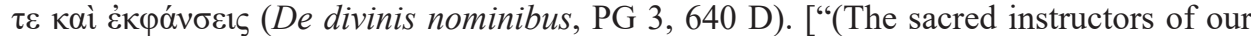
theological tradition call) the "Divine Unions" the hidden and unrevealed sublimities of the super-unutterable and super-unknown Isolation; but the "distinctions," the goodly progressions and manifestations of the Godhead" (trans. J. Parker, 16-17)]. The difference between unions and distinctions presented by pseudo-Dionysius is possibly the main topic of the second chapter of his treatise De divinis nominibus.

33 Cf. In Platonis Parmenidem comentarii, 742.24-760.17 (Proclus. Commentaire sur le Parménide de Platon, eds. C. Luna - A.Ph. Segonds, Paris 2007).

34 Cf. De Principiis III 1.1-46.8 (Damascius: Traité des premiers principes: De la triade et de l'unifié, eds. L. G. Westerink - J. Combès,,Paris 1989). Cf. for instance, J. Combès, Damascius lecteur du Parménide, „Archives de Philosophie” 38 (1975) p. 33-60. 
Attempting to discuss any possible meaning, John Damascene investigates two typical phrases, which express more clearly the mean-

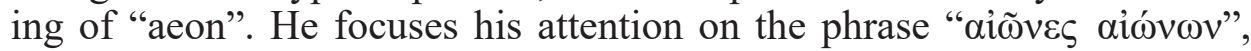
where the plural shows the inclusiveness as a state and comprehensiveness as an endless potentiality. Specifically, he says that the seven aeons of this world include many aeons, namely, many human lives, and each aeon as a somehow genus - includes all the aeons ${ }^{35}$. By mentioning exclusively the aeons, everything is placed in the intra-world level. However, when he

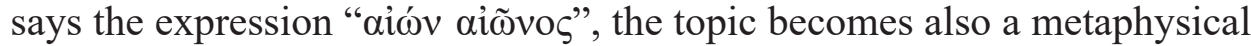
one, since this phrase combines the present aeon with the future one, i.e. it connects the development of the created world in time with an eschatological prospect, in the context of which time, as a transition from the past to future, will be of no importance. As he points out, the main quality of the future aeon would be the $\dot{\alpha} \tau \varepsilon \lambda \varepsilon v i \tau \eta \tau o v$ (never-ending), which is related with both true life and hell ${ }^{36}$. And that is why one may use the term "eternal" for both these two, which in fact are not just meant in the sense of created and limited places; they basically show relations with God. In this sense, heaven and hell are symbols and images that may be approached according to the theological terms set by a healing - but not juridical - salvation. Here one may see John Damascene's explanations discussed in his Dialogue against the Manichees about how the receptivity of every created being defines the states of heaven and hell; more specifically, in his view heaven is participation in God's gifts and, metaphorically, happiness, while hell is unparticipation and deprivation of what is desired, therefore, it is actually sorrow ${ }^{37}$. It becomes clear that the concepts have a special meaning. So, more specifically, heaven is in fact a "reversion" of the rational beings

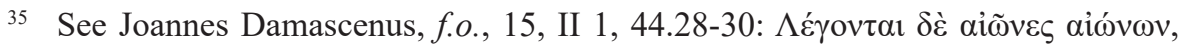

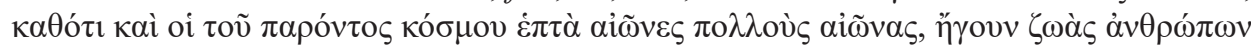

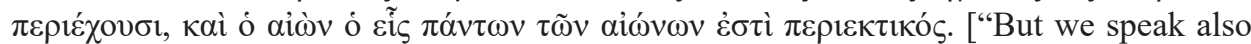
of ages of ages, inasmuch as the seven ages of the present world include many ages in the sense of lives of men, and the one age embraces all the ages, and the present and the future are spoken of as age of age" (S.D.F. Salmond, 526)].

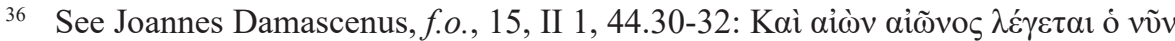

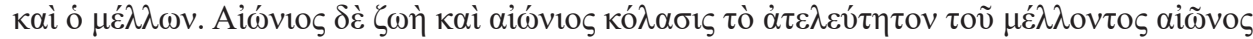
$\delta \eta \lambda$ oi. ["Further, everlasting life and everlasting punishment prove that the age or aeon to come is unending" (S.D.F. Salmond, 526)].

37 See Joannes Damascenus, Dialogi contra Manichaeos 1, 2, PG 94, 1545 D-1548

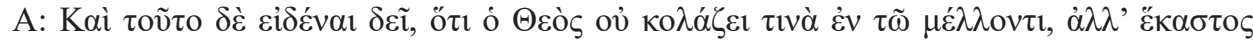

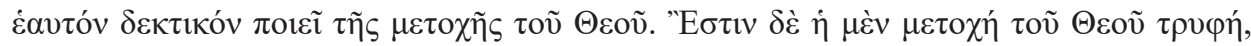

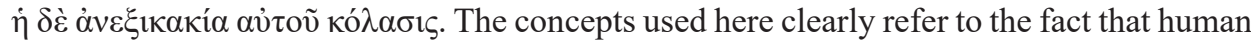
is the only responsible for the quality of his future life according to the choices he made in his intra-cosmic life. 
to the completeness of their development and that is why one may speak about a course of perfection, at the end of which persons with a divine form enter the world of God. Note that this state concerns both the sensible and the supersensible (i.e. the angelic) world, which as a created whole move together in a dynamic way towards a future state, following a new ontological course - after the moral failure of man. On the other hand, hell is the state of non-participating in the supreme Principle and the others. With no doubt though, created beings preserve their free will.

In order to emphasize the eternal nature of the above-mentioned relations between the created beings and God, John Damascene makes some metaphorical descriptions, which aim at showing clearer the difference between the concepts when they are placed in the cosmological area and when they are placed in the metaphysical-eschatological field in the light of Henology. So, provided that heaven and hell are eternal states, according to John Damascene, time is definitely an intra-world measure that only matters to the world of becoming, i.e. the place of the created beings, since it is numbered by days and nights. However, after the event of resurrection - which includes both the souls and the bodies - the created world will no longer exist under the present terms. That is why there will be no succession, but time will receive a new meaning and will be re-defined on the basis of an ontological differentiation between it and God, on the basis of the dialectical opposition between heaven and hell. So, the spacetime measurement according to the movement of the planets will no longer exist. By extension, there will be no generation and corruption of the created beings, but just the following two states: the incessant day, during which the sun of righteousness will shine brightly only for the righteous people, and the deep and endless night, in which the sinners will be put ${ }^{38}$. By these metaphorical descriptions and through eternal relational states, John Damascene's purpose is to show from another point of view how close or how far is naturally - depending on which created rational beings we have in mind - God to or from the created beings.

Regarding the eternal night, the descriptions are not about an end of life, since this would take out of God any creative energy that he owns. Instead, he means the permanence and infiniteness of the choices made

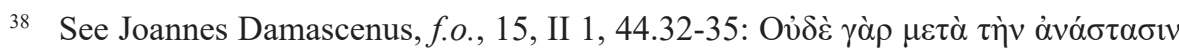

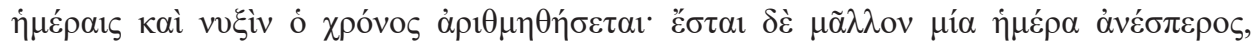

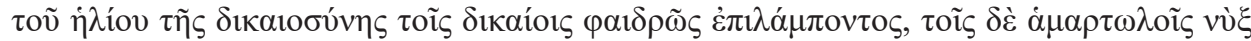

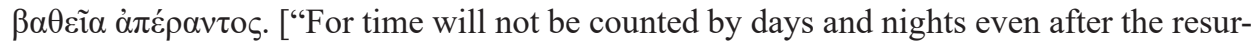
rection, but there will rather be one day with no evening, wherein the Sun of Justice will shine brightly on the just, but for the sinful there will be night profound and limitless" (S.D.F. Salmond, 526)]. 
by God, given conditions for the Christian teaching, while they also define how human actions will be judged and to what place human will be lead. Moreover, the concepts "righteous" and "sinful" are not just about people who have or have not committed a sin, since denying nature is not something acceptable exactly because of the original sin and, by extension, the weakness of the human nature ${ }^{39}$. The words here describe a distinction between humans who regret and those who do not but remain impenitently in an unnatural state ${ }^{40}$. This is clearly a choice that every human being is able to make according to their own free will, which is a property provided by God; having in mind that man is made on God's image, free will could never be raised ${ }^{41}$. The axiological question is as follows: do humans use their free will according to the divine planning? In order to give an answer, it is necessary to see how every human being understands the meaning of it and how they utilize it in order to reach God.

So, accepting that temporality is compatible only with the creation, since time was created together with the natural world and follows its evolution, the question that is now raised is how one may measure the period of a thousand years for the restoration that was postulated by Origen ${ }^{42}$. John Damascene's suggestion is that we should not have in mind a time

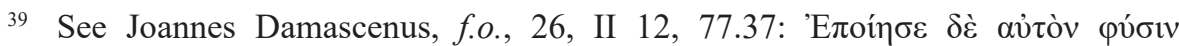

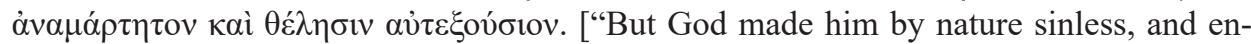
dowed him with free will" (S.D.F. Salmond, 549)]. For a general approach of the topic, cf. Gilson, L'esprit de la philosophie médiévale, 284-303.

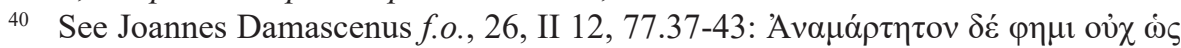

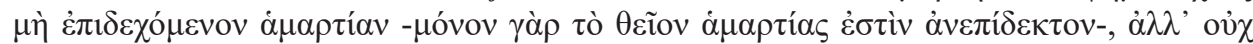

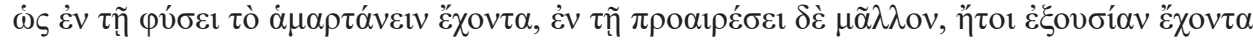

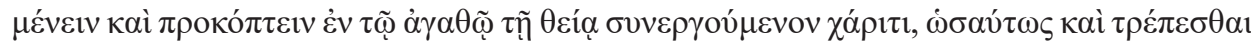

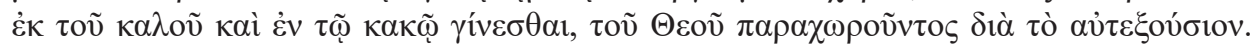
["By sinless, I mean not that sin could find no place in him (for that is the case with Deity alone), but that sin is the result of the free volition he enjoys rather than an integral part of his nature; that is to say, he has the power to continue and go forward in the path of goodness, by co-operating with the divine grace, and likewise to turn from good and take to wickedness, for God has conceded this by conferring freedom of will upon him" (S.D.F. Salmond, 549)]. For a systematic approach, cf. Gilson, L'esprit de la philosophie médiévale, 284-323.

41 On the concept of "the image of God" in John Damascene and its moral and gnoseological extensions in human, see J.R. Payton, John of Damascus on Human Cognition: An element in his Apologetic for Icons, „Church History” 65 (1996) v. 2, p. 173-183.

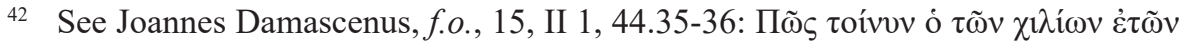

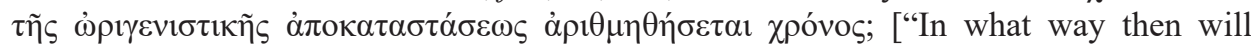
the period of one thousand years be counted which, according to Origen, is required for the complete restoration?" (S.D.F. Salmond, 526)]. 
sequence or, by extension, measure of time in terms of the created world when speaking of God-related situations, since God is the completely timeless reality. What is more, any temporal definitions, apart from the fact that they are only related with the created world, show the beginning and end, which have no place in the forthcoming eternal states of heaven and hell. In this sense, the distance between the created world and the supreme Principle is not only temporal but basically ontological: God is uncreated, beginningless, endless, completely transcendent and exists before the entire created world; on the other hand, the created world temporally and ontologically follows the Creator and depends on him; it develops according to the principles set by him; the course towards its completion is permanently determined by exactly this goal. Moreover, the future heaven or hell as conditions that will set particular terms of living will be eternal ontological givens. This mainly rhetorical question shows John Damascene's opposition to the millennialism and Origen's restoration of all things ${ }^{43}$.

Being more specific on the above, the following arise: at first, millennialism was a Christian belief, which was later rejected as heretical. The main position was that there would be a golden age or, else, a worldly heaven, where Jesus Christ would put an end to the evil and, before the final judgment, would reign over the entire world together with the righteous, loving and resurrected people. This period of a thousand years would not be the end of the world, for there would be a final battle with Satan. God would be the winner, and then the final judgment would come. This was a story based on a literal grammatical interpretation of Apocalypse 20,1-10. Note, that there were also symbolic interpretations of that extract, considering that the Kingdom of a thousand years (the number was also considered in a symbolic manner) takes place only in mind. Origen suggested this symbolic approach ${ }^{44}$.

One of his main positions was about the final restoration of all things ${ }^{45}$. According to this, everything would turn into their original state, a story

43 According to A. Louth, "John is drawing on a long tradition, going back at least to Origen, in seeing meditation on Scripture as leading to a loving relationship with Christ" (St. John Damascene: Tradition and originality in Byzantine theology, p. 45).

44 On Origen's views, cf. for instance J. Danielou, Sacramentum futuri: Études sur les origins de la typologie biblique, Paris 1950; A. Louth, The origins of the Christian mystical tradition: From Plato to Denys, Oxford 2007, p. 51-72; I.L.E. Ramelli, Origen, Patristic Philosophy, and Christian Platonism Re-Thinking the Christianisation of Hellenism, „Vigiliae Christianae” 63 (2009) v. 3, p. 217-263.

45 This expression is found only once in the Holy Bible and, more specifically, in the Act. 3,19-21, where it means the kingdom of heaven to come and Jesus Christ is the center of this course, which is gifted and is constantly supported and strengthened 
based on the fact that hell is not an eternal state, since fire does not punish but purifies. It is to be mentioned that fire was not for Origen a created material, but showed the difficult state of someone who suffers by compunctions ${ }^{4}$. This was actually a moral orientation by which self-references and reconstructions were made and, therefore, its usage resulted in metaphorical descriptions. In this sense, Origen suggested that the demons would also have eventually the opportunity to save themselves and to come close to $\mathrm{God}^{47}$. It was clear for him that through a process of catharsis everything would communicate with God and eventually evil would be totally defeated; so, everything would subject to the supreme Principle and would be restored in order resurrection to follow. This was a way for everything - as spirits that would have reached the final moral perfection and would have been set free from any kind of matter - to reverse to the original state ${ }^{48}$. The end of the world had to be the same with the beginning, in the form of a cycle.

The most important thing arisen from the above was the connection of the concept of restoration with the idea of a life cycle, which was actually more appropriate for a philosophical approach that was rather far from the Christian renovation of the created world that would take place after the future Kingdom of heaven would come. It should be also explained that, by his theory on restoration of all things, Origen attempted to form an ecclesiastical tradition that would put an end to the prospect of hell.

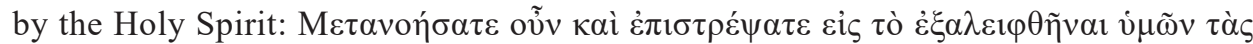

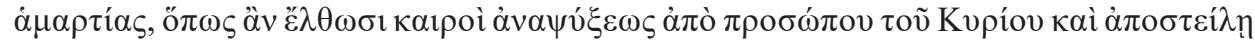

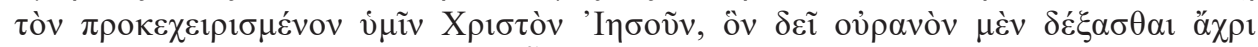

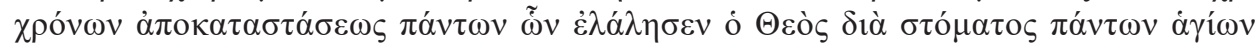

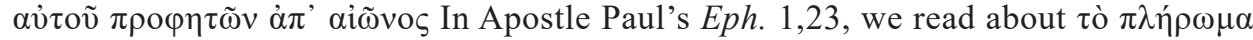

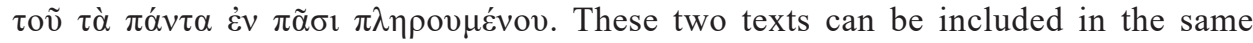
soteriological-eschatological perspective, the Kingdom of heaven. On a systematic approach of the topic, cf. for instance, W. Pannenberg, Theology and the kingdom of God, Philadelphia 1969.

46 Cf. N. Cohn, Pursuit of the Millennium: Revolutionary millenarians and mystical anarchists of the middle ages, Oxford 1970, p. 29.

47 Origenes, De principiis, eds. H. Görgemanns - H. Karpp, Origenis: De Principiis Libri IV, Darmstadt 1985, II, 10, 8. According to our view, this explanation is based on the doctrine about Origen's restoration of all things, which should be approached very carefully, since it is still one of the major Christian questions to be answered. On this, see L.R. Holliday, Will Satan Be Saved? Reconsidering Origen's Theory of Volition in "Peri Archon”, „Vigiliae Christianae” 63 (2009) v. 1, p. 1-23.

48 On Origen's soteriology in general, see for instance I.L.E. Ramelli, Christian Soteriology and Christian Platonism: Origen, Gregory of Nyssa, and the Biblical and Philosophical Basis of the Doctrine of Apokatastasis, „Vigiliae Christianae” 61 (2007) v. 3, p. 313-356. 
The way in which the created beings would somehow face their Creator in order a cosmic renewal to be accomplished was the purification of the souls. Free will, however, as a property provided by God, is constantly a quality of the created beings, including the purified ones. Taking into account the possibility of choice, it becomes clear that the new world suggested by Origen could fall in sin at any time, so a new process for perfection would follow. Although Origen does not suggest something like this, this could be endless. Nevertheless, Origen's theory is different from the Christian Eschatology as it was later formed; furthermore, a literal interpretation of the thousand years of heaven on earth before the last judgment is also not acceptable ${ }^{49}$. Finally, John Damascene also rejects the possibility for hell to be a non-eternal state, since this would change totally the Christian doctrine. He is absolutely clear: heaven will be an incessant day, while the opposite will be an endless night, with the adjectives in both cases showing unchangeable states that remain always exactly as they are.

Precisely this sense of eternity is, according to John Damascene, the way in which God exists: he is the power that created all the worlds and the aeons. Moreover, he is pre-eternal and one, but instead of being the person who imposes heaven or hell, he is the one who defines by his presence

49 The thousand years are a symbolic number, which actually means a long period of time, as it is confirmed from many passages in the Scriptures. For instance, 2Ptr. 3,8; Ps. 89,$4 ;$ Mk. 13,32. On the concept of time in Origen, cf. P. Tzamalikos, Origen and the Stoic View of Time, „Journal of the History of Ideas” 52 (1991) v. 4, p. 535-561, who also attempts to compare Origen's views with those of the Stoics. It is to be mentioned that

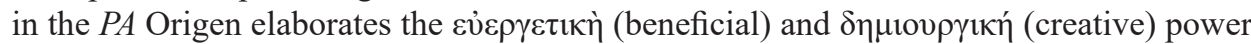
of God, which is complete by virtues and providential for the created beings. Specifically:

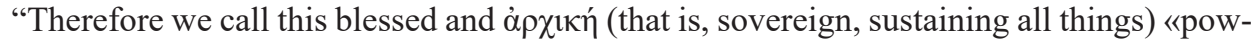

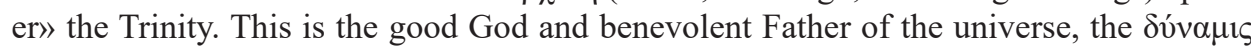

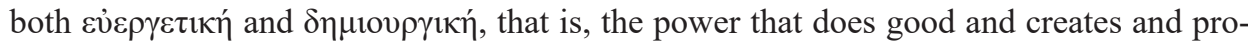
vides. It is both absurd and impious to suppose that these powers have been idle at any time even for a moment. Indeed, it is unlawful to entertain the slightest suspicion that these powers, through which primarily God is worthily known, should at any time have ceased from working worthy of him and have become inactive. For neither can it be supposed that these powers which are in God, more, which are God, could have been hindered from without, nor, on the other hand, with nothing obstructing them, can it be believed that they were reluctant or neglected to act and work things worthy of themselves. It is therefore not possible to imagine any moment whatsoever when that beneficent power did not work good. Whence it follows that there always were those for whom it worked good, that is, his works or creatures, and that, doing good by other and desert, God dispensed, in the power of this providence, his benefits upon them. And by this it seems to follow that at no moment was God not creator, nor benefactor, nor provident" (Origen: On First Principles, v. 1, ed. J. Behr, Oxford - New York 2017, p. 85 and 87). 
the comparative evaluations that result in these two states ${ }^{50}$. In these words, the Christian thinker completes his reasoning on the definition of the concept of aeon, its properties and its relation with both the created world, in the sense of a process, and God, in the sense of a source.

\section{Conclusions}

According to the former discussion, we could argue that there is a circular structure in the chapter elaborated in this study, which aims to emphasize the reason behind the text, its main idea and conclusion; this is a combination that reveals the unquestionable meaning of the concepts and, by means of this integrity or at least in a special in each case way, the naturally ontological permanent quality of the two levels, that is, the created world and God. However, it should not escape attention how important teleology is for the reduction-ascent of the creation to the supreme Principle, which actually determines and redefines the intentionally and consciously relationship terms, so as the substantial difference between the created beings and God to turn into an approach and a sort of communion. So, the ideas of the divine transcendence and the divine immanence together with the free will of the created beings provided by God show in the context of the divine economy the general course followed by both a timeless and spaceless reality, i.e. God, and the created world, either it is the one that is subject to time and space or it is that which is placed in eternity. It could be said that John Damascene's theory on aeon and time establish an optimist ontological and anthropological model, provided that human makes the right gnoseological and moral choices and performs the right actions in order to deal with what God defines. Furthermore, this optimist model is reinforced by the fact that a concept such as aeon, which refers to a divine transcendent property, describes the way in which the natural beings exist as well ${ }^{51}$. Therefore, our study could also have the title "metaphysical and cosmological approaches of the concept of 'aeon"'.

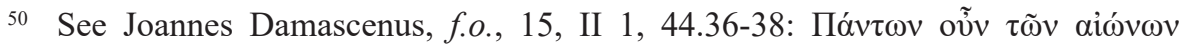

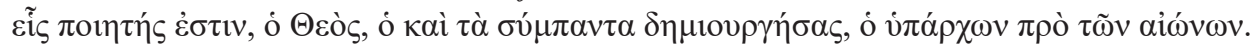
["Of all the ages, therefore, the sole creator is God Who hath also created the universe and Who was before the ages" (S.D.F. Salmond, 526)]. In this extract, ontological monism appears to be non-negotiable.

51 A historian of philosophy would like to detect the similarities of the Christian thought of John Damascene with those arisen from Proclus' Neoplatonic views following his comments on Timaeus. Actually, in the second book of this treatise Proclus says 


\title{
'Aeon' as an Expression of Metaphysics of Transcendence and Metaphysics of Immanence in John Damascene
}

\author{
(summary)
}

In this study, we are discussing the concept of "aeon" in John Damascene. Specifically, relying on his treatise entitled An exact Exposition of the Orthodox Faith, we first of all investigate the relation between aeon and the created world, as well as the resulted from it combination of Cosmology with Eschatology. Subsequently, we focus on the relation between aeon and the Holy Trinity, taking into account all the ways in which it is manifested, as well as the combination of Henology with Eschatology. Throughout the entire reasoning, it arises that the Christian thinker utilizes the Words, that is, the divinely inspired texts, as an objective proof for the Christian validity of his arguments. The most important conclusion drawn is that the term "aeon" has many meanings and that each one of them depends on whether it refers to the metaphysical or natural ontological level.

Keywords: John Damascene; An exact Exposition of the Orthodox Faith; eternity; aeon; time; Origen

\section{Bibliography}

\section{Sources}

Basilius Magnus, Homilia 2 in hexaemeron, PG 29b, 27-52.

Damascius, De Principiis, eds. L.G. Westerink - J. Combès, Damascius: Traité des premiers principes: De la triade et de l'unifié, Paris 1989.

Dionysius Areopagita, De divinis nominibus, PG 3, 585-984, trans. J. Parker, Dionysius the Areopagite, Works (1987) by Dionysius the Areopagite, Ipswich 2004.

Gregorius Nyssenus, Homilia 6 in Ecclesiasten, PG 44, 1264-1278.

Gregorius Nyssenus, Quod non sint tres dii, PG 45, 116-136; ed. Fridericus Mueller, Gregorii Nysseni: Opera Dogmatica Monora, v. III/1, Leiden 1958, p. 37-57.

Gregorius Nyssenus, Tractatus adversus Graecos ex communibus notionibus, PG 45, 176185; ed. Fridericus Mueller, Gregorii Nysseni: Opera Dogmatica Minora, v. III/1, Leiden 1958, p. 19-39.

Iohannes Damascenus, De fide orthodoxa libri quattuor, ed. Bon. Kotter, Die Schriften des Johannes von Damaskos, v. 2, Berlin - New York 1973; Iohannes Damascenus, An exact Exposition of the Orthodox Faith, trans. S.D.F. Salmond, Oxford 1898.

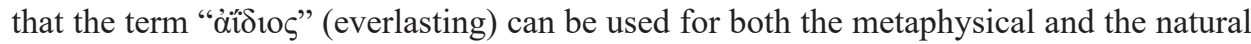
world. Cf. In Platonis Timaem comentarii IV 239.2-6 and III 100.1-15 (Procli Diadochi In Platonis commentaria, v. 1-3, ed. E. Diehl, Amsterdam 1965). However, it does not have the same meaning with the term " $\alpha i \omega$ vios" (without beginning or end). The challenge to investigate the two thinkers is great. 
Iohannes Damascenus, Dialogi contra Manichaeos, PG 94, 1503-1584.

Maximus Confessor, Ambigorum liber, PG 91, 1031-1418.

Maximus Confessor, Capitum theologicorum et oeconomivorum duae centuriae, PG 90, 1083-1462.

Origenes, De principiis, eds. H. Görgemanns - H. Karpp, Origenis: De Principiis Libri IV, Darmstadt 1985; Origenes, Peri Archon, ed. J. Behr, Origen: On First Principles, v. 1, Oxford - New York 2017.

Plato, Timaeus, ed. A. Rivaud, Platon Oeuvres completes Timee et Critias, Paris 1925.

Proclus, In Platonis Parmenidem comentarii, eds. C. Luna - A.Ph. Segonds, Proclus. Commentaire sur le Parménide de Platon, Paris 2007.

Proclus, In Platonis Timaeum comentarii, ed. E. Diehl, Procli Diadochi In Platonis commentaria, v. 1-3, Amsterdam 1965.

\section{Studies}

Aubenque P., Le problème de l'être chez Aristote, Paris 1991.

Aubin P., Plotin et le Christianisme, Paris 1992.

Benakis L., To próvlimma ton genikón en noión kai o ennoiologikós realismós ton Vyzantinón, „Filosofía” 8-9 (1978-1979) p. 311-340.

Benakis L., Chrónos kai Aión „Filosofía” 10-11 (1980-1981) p. 398-421.

Brann E., Time in the Timaeus, in: The Music of the Republic: Essays on Socrates' Conversations and Plato's Writings, Philadelphia 2004, p. 273-278.

Cohn N., Pursuit of the Millennium: Revolutionary millenarians and mystical anarchists of the middle ages, Oxford 1970.

Combès J., Damascius lecteur du Parménide, „Archives de Philosophie” 38 (1975) p. 33-60.

Cullman O., Christ and Time: The Primitive Christian Conception of Time and History, transl. F.V. Filson, London 1962.

Danielou J., Sacramentum futuri: Études sur les origins de la typologie biblique, Paris 1950.

Dodds E.R., Proclus. The Elements of Theology, Oxford 1933.

Festugière A.-J., La révélation d'Hermès Trismégiste, v. 2, Paris1990.

Florovsky G., Thémata Orthodóxou theologías, transl. S. Papalexandropoulou, Athens 1973.

Giet S., Basile de Césarée. Homélies sur l'hexaéméron, Paris 1968.

Gilson É., L'esprit de la philosophie médiévale, Paris 1989.

Holliday L.R., Will Satan Be Saved? Reconsidering Origen's Theory of Volition in "Peri Archon”, „Vigiliae Christianae” 63 (2009) v. 1, p. 1-23.

Larchet J.-C., La théologie des énergies divines: Des origines à saint Jean Damascène, Paris 2010.

Louth A., Denys the Areopagite, London - New York 2002. 
Louth A., St. John Damascene: Tradition and Originality in Byzantine Theology, Oxford 2002.

Louth A., The origins of the Christian mystical tradition: From Plato to Denys, Oxford 2007.

Matsoukas N., Dogmatiki kai Symvoliki Theología, v. B, Thessaloniki 2003.

Payton J.R., John of Damascus on Human Cognition: An element in his Apologetic for Icons, „Church History” 65 (1996) v. 2, p. 173-183.

Pannenberg W., Theology and the kingdom of God, Philadelphia 1969.

Ramelli I.L.E., Christian Soteriology and Christian Platonism: Origen, Gregory of Nyssa, and the Biblical and Philosophical Basis of the Doctrine of Apokatastasis, „Vigiliae Christianae" 61 (2007) v. 3, p. 313-356.

Ramelli I.L.E., Origen, Patristic Philosophy, and Christian Platonism Re-Thinking the Christianisation of Hellenism, „Vigiliae Christianae” 63 (2009) v. 3, p. 217-263.

Roques R., Structures théologiques de la Gnose à Richard de Saint-Victor, Paris 1962.

Scazzozo P., La teologia antinomica dello pseudo-Dionigi, Aevum 49 (1975) p. 1-35.

Schürmann E., L’ hénologie comme dépassement de la métaphysique, „Les études philosophiques" 3 (1982) p. 331-350.

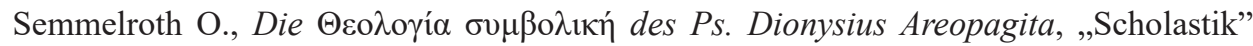
27 (1952) p. 1-11.

Semmelroth O., Gottes uberwesentliche Einheit. Zur Gotteslehre des Ps-Dionysius Areopagita, „Scholastik” 25 (1950) p. 209-234.

Töröner M., Union and Distinction in the Thought of St. Maximus the Confessor, Oxford 2007.

Trouillard J., Proclos, Eléments de Théologie, Paris 1965.

Tzamalikos P., Origen and the Stoic View of Time, „Journal of the History of Ideas” 52 (1991) v. 4, p. 535-561. 